AperTO - Archivio Istituzionale Open Access dell'Università di Torino

\title{
Spirituality and Catholicism: the Italian Experience
}

\section{This is the author's manuscript}

Original Citation:

Availability:

This version is available http://hdl.handle.net/2318/122346

since

Terms of use:

Open Access

Anyone can freely access the full text of works made available as "Open Access". Works made available under a Creative Commons license can be used according to the terms and conditions of said license. Use of all other works requires consent of the right holder (author or publisher) if not exempted from copyright protection by the applicable law. 


\section{AUTHOR QUERIES}

\section{Journal id: CJCR_A 475613}

Corresponding author: STEFANIA PALMISANO

\section{Title: Spirituality and Catholicism: The Italian Experience}

\section{Dear Author}

\section{The following queries have arisen during the editing of your} manuscript. Please answer the queries by marking necessary corrections at the appropriate positions on the PROOFS. Do not answer the queries on the query sheet itself. Please also return a copy of the query sheet with your corrected proofs.

Thank you for your cooperation

Notes Please note that JCR's referencing follows the MLA style. References have been adjusted to this style where necessary. Some of the queries have arisen from the way references are handled within MLA.

Please bear in mind that JCR has an international readership and this needs to be reflected in the way articles are written. Hence, for example, the need to explain specialist vocabulary.

Pls note that spelling in this article has been adjusted to British spelling, as both US and British spellings were mixed.

1 Pls provide reference(s) for World Values Survey, 1990 and 2000.

2 Is this Flanagan and Jupp? Or is it Flanagan's "Introduction"? If this is the case, the page number does not match the page range given in the bibliography.

3 The last sentence ("At least this is the working hypothesis.") is not clear. Pls clarify. 
$4 \quad$ Which of Heelas's article is referred to here?

$5 \quad$ Are there not other authors for The Spiritual Revolution?

$6 \quad$ Pls provide the page numbers for the chapter by Voas \& Bruce.

$7 \quad$ Pls provide the page numbers for the chapter by Woodhead.

8 Pls list the co-authors of Zinnbauer and Pargament. 


\section{Spirituality and Catholicism: The Italian Experience}

\section{STEFANIA PALMISANO}

ABSTRACT At the start of the twenty-first century, Catholicism is still the prevailing belief system of most Italians, but a recent project on Italian religion and spirituality, carried out in 2006, has found that Italians are now more interested in spirituality, that they might describe themselves as 'spiritual, but not religious', and that they privilege the 'god within' rather than the transcendent God of traditional Catholic belief. This article presents the findings of The Italian Religion and Spirituality Project and focuses on what Italians mean by a 'spiritual life'. After an overview of the growing interest in spirituality in the Italian socio-cultural setting, various aspects are illustrated: Italians' self-assessments of religiosity and spirituality; meanings of spirituality; involvement in church and/or in holistic activities; various attitudinal variables, such as preference, beliefs, identification, and willingness to lead a religious and/or a spiritual life. A typology is then elaborated to study the profiles of four groups: (1) neither religious nor-spiritual; (2) religious, but not spiritual; (3) spiritual, but not religious; (4) both spiritual and religious. Two key concepts, intra-religious spirituality and extra-religious spirituality, are introduced to examine some of the ways in which spirituality finds expression in the context of contemporary Catholicism. After describing the different ways Italians understand the term 'spirituality', I identify three profiles of

20 spirituality: 'ethic', 'religious', and 'inner-self'. Finally, the significance of the 'God within' is discussed, a phenomenon that is perhaps more readily associated with Protestant forms of holistic spiritualities, but is surprisingly also significant within Italian Catholicism.

\section{Introduction}

In the last decade, many studies of religion and religiosity have collected a considerable amount of information and statistics on the complexity and differentiation that characterises the state of Catholicism in Italy today (e.g. Abbruzzese; Cesareo et al.; Diotallevi; Garelli, L'Italia cattolica). Italian researchers (Garelli, Guizzardi and Pace)—who show that Catholicism is still

30 the prevailing religion-have coined the expression 'peculiar pluralism' to claim that, although Italian society continues to portray itself as a relatively homogenous society in religious terms, Italian Catholics interpret their practical involvement with the Catholic Church in a variety of ways. This includes a number of ways of conceiving the meaning of belonging to the Church, varying forms of religious practice, and the fact that a belief system with which one identifies does not necessarily have an impact on one's social and individual life in any significant way. In 2006, a research team at the University 
of Turin, consisting of Franco Garelli (director), Roberto Scalon and myself (full-time researchers), embarked on The Italian Religion and Spirituality Project, with the aim of showing that, although alternatives spiritualities might be regarded as a predominantly Protestant phenomenon, such spiritualities are also significant within Italian Catholicism. ${ }^{1}$ Data collection took place in the Winter of 2006, involving a survey by Eurisko, a private Italian Research Institute, which covered all of Italy. The sample of 3,160 individuals is representative of the Italian population of men and women whose ages range from 16 to 74 years. $^{2}$

The novelty of The Italian Religion and Spirituality Project 2006 (its findings appear in print for the first time), ${ }^{3}$ when compared with previous surveys, is that it investigated more thoroughly, at both the theoretical and the

50 empirical level, the distinction between religion and spirituality, particularly looking at the meanings which Italians attach to the term 'spirituality'. Additionally, this study contributes to the recent and now rapidly growing research on spirituality in a number of European countries by exploring its quantitative significance. Several questions were asked (through telephone random sampling) using the wording of previous surveys to enable comparison over time. New questions were designed to increase our understanding of innovations in the religious scene. Above all, these questions made it possible to explore the distribution and content of spirituality among the Italian population. Such an analysis involved a wide range of new items and

60 indicators, including self-assessment of religiosity and spirituality; meanings of spirituality; involvement in church and/or holistic activities; various attitudinal variables, such as preference, beliefs, identification, and willingness to lead a religious and/or a spiritual life.

The main topic of this article is thus an exploration of what Italians mean by

65 'spiritual life'. After providing an overview of the growing interest in spirituality in the Italian socio-cultural setting, the article illustrates the findings from the survey data which the research team gathered on spirituality: Italians' self-assessment of religiosity and spirituality; their relationship with institutionalised religion, their opinion of traditional religious authorities and the statements of these authorities regarding truth and salvation; their involvement in church and holistic activities, and their quest for spiritual growth. Based on the findings of Italians' self-assessment of religiosity and spirituality, a typology is formulated to study the profiles of four groups: those (1) neither religious nor spiritual; (2) religious, but not spiritual; (3) spiritual, but not religious; (4) both spiritual and religious. Two key concepts, intra-religious spirituality and extra-religious spirituality, are introduced to examine some of the ways in which spirituality finds expression in the context of contemporary Catholicism. After describing the different ways in which Italians understand the term 'spirituality', three types of spirituality are identified: 'ethic', 80 'religious', and 'inner-self'. Finally, the significance of the notion of 'God within' is discussed, a phenomenon that is perhaps more readily associated with Protestant forms of holistic spiritualities, but that is surprisingly also significant within Italian Catholicism: 36\% of Italians declared in the research on moral and religious pluralism (RAMP survey of 1998) that 'God is something within each person and in nature'. 


\section{Contemporary Interest in Spirituality}

As in many other European countries (see Heelas and Woodhead; Houtman and Aupers, "Oriental Religion"; Ketola; Lynch), the language of spirituality has recently come into its own in Italy. Expressions like 'mind-body-spirit' 90 (mente, corpo, spirito) have entered popular consciousness. Yoga, reiki, shiatsu, aromatherapy, naturopathy, osteopathy, and other forms of holistic practice have become more widespread in the past decade. Even a cursory glance around the local bookshop or a stroll through the shopping centre leaves little doubt that Italians' interest in these matters is increasing. Further, in 2006, "Spiritualsearch", the first specialised Italian web site specifically oriented towards spiritual content, was created. It provides many links, not only to the web sites of different religious traditions, but also to mediums, clairvoyants, spirit guides, and other spiritual services. In addition, there are sections dedicated to a range of spiritual practices and to subjects such as astrology, divination, and esoterism.

This snapshot does not necessarily indicate that growing attention to and participation in the 'holistic milieu' or 'alternative spiritualities' mean an increase in the 'spiritual quest'. Many who are active in these areas do not consider their practices or their interests to be of spiritual significance.

105 However, many others do. What is indisputable is the evidence which shows the turn towards a "person-centred" or "subjective-centred" culture (Taylor). According to Heelas and Woodhead, such a shift in the sacred sphere is associated with spirituality, the sacred serving the cultivation of a unique subjective life.

110 The increasing emphasis on a 'subjective-centred' culture has emerged in many areas: in the cultures of health (with person-centred complementary and alternative medicine), work (the turn towards the personal development of employees, including more care for their well-being), education (the introduction of organic food in school meals and the presence of alternative

115 and complementary therapists who provide natural health care for staff and students), and purchasing. As in other European countries, in Italy, most of the findings and knowledge about this topic are based on qualitative research. However, some statistical data are available from surveys concerning alternative therapies and the well-being business.

120 The figures shown in the last Multiscopo inquiry ("Conditions of health and the use of health services 1999-2000") demonstrate that, between 1991 and 1999, the number of Italians who used alternative therapies nearly doubled. In 1999, approximately 9 million Italians (16\% of the population) claimed they had used alternative therapies in the three years preceding the interview. ${ }^{5}$ Later studies

125 of complementary and alternative medicine (Giarelli, Roberti di Sarsina and Silvestrini) show that homeopathy is the most frequently used, followed by various versions of massage, herbal therapy, and acupuncture.

Holistic spirituality is also becoming increasingly important in the area of well-being. The fitness well-being sector has expanded enormously in the last

130 few years. Its multiple fields emerge from the infectious effect of consumer models and fashionable ideologies and philosophies: plastic surgery, aesthetic medicine, various schools of massage, organic food, complementary and alternative medicine, recycling, and much more. In addition, according to the 
Italian Association of Wellness, there is an increasing interest in weekends, holidays, and even hour-long sessions at spas, ayurvedic resorts, and health farms. This has resulted in about 24,000 wellness centres in Italy, counting 18 million customers the last year. ${ }^{6}$

Equally important are the seminars, training courses, and workshops of soft capitalism, which are more concerned with the personal qualities of participants

140 than with abstract or functional procedures. The new imperative in human resources management, particularly in the area of customer service, is developing employees' "emotional intelligence" (Goleman). For instance, the Italian banking system offers courses which teach employees how to be more empathetic towards people to improve relationships with customers. In 2005, the

145 SanPaolo bank (now Intesa-SanPaolo, after a merger) developed a human resources management project called "Building the Future on People's Own Values and Souls" for their employees. This included an empowerment course called "Managerial Identity: A Feminine Route", for women employees, aimed at improving self-esteem and employees' ways of 'living the work'. In these lessons,

150 the theoretical aspects related to "how to augment one's self-esteem", supported by relaxation techniques, yoga, and autogenic-training exercises. ${ }^{7}$

Researchers from several European countries are taking the study of spirituality on board. In fact, Heelas ("Challenging") suggests that the sociology of religion should be renamed the 'sociology of religion and

155 spirituality'. However, students of sociology of religion in Italy have only recently adopted the concept of spirituality (Garelli, Guizzardi and Pace; Giordan, "Dalla religione"; Tra religione). Although Italian sociologists pointed out some elements which would now be referred to as 'spirituality' in the mid-1980s, it is only since 2003 that they have begun to make explicit use of

160 this concept. Garelli (see Garelli, Guizzardi and Pace) was the first to use it to describe the Italian situation. However, as we will see, when analysing the figures for Italy in the research on the moral and religious pluralism of Italians (RAMP survey of 1998), he argues that the inclination of Italians to consider themselves as 'religious' is more common than their inclination to interpret life

165 in spiritual terms.

However, the considerable changes in the public sphere described above make it clear that there is a pressing need to develop new research strategies, including additions to questionnaires, in order to (i) further refine the heuristic range of the concept of spirituality and (ii) pay increased attention to the state of spirituality in Italy.

Indeed, ten years have passed since the RAMP study. What has changed in the meantime? Do Italians still regard themselves as more 'religious' than 'spiritual'? What kind of 'spiritual life' do Italians seem to live? The Italian Religion and Spirituality Project 2006 aimed to address these questions by means of a wide

175 range of new items and indicators. I shall now provide an outline of the most significant findings from the survey.

\section{Indications of Spirituality in the Survey Data}

Following the RAMP questionnaire of 1998, The Italian Religion and Spirituality Project 2006 asked respondents to indicate the extent to which they considered 
Table 1. Self-assessment of Religiosity and Spirituality: Comparison between 1998 and $2006(\%)$.

\begin{tabular}{|c|c|c|c|c|c|c|}
\hline & \multicolumn{3}{|c|}{ religious person } & \multicolumn{3}{|c|}{ spiritual person } \\
\hline & $\% 2006$ & \% 1998 & $p \%$ & $\% 2006$ & $\% 1998$ & $p \%$ \\
\hline not at all/a little & 25 & 21 & +4 & 23 & 28 & -5 \\
\hline medium/high & 73 & 78 & -5 & 74 & 68 & +6 \\
\hline I don't understand the question. & 2 & 1 & +1 & 3 & 4 & -1 \\
\hline Total & 100 & 100 & & 100 & 100 & \\
\hline$(\mathrm{N} 2006=3160 ; \mathrm{N} 1998=2149)$ & & & & & & \\
\hline
\end{tabular}

Sources: RAMP 1998; The Italian Religion and Spirituality Project 2006.

180 themselves to be religious and to have a spiritual life. They were asked, on a Likert scale ranging from 7, if they definitely thought of themselves as religious/spiritual ( 1 if they definitely did not). Table 1 summarises the responses in comparison with RAMP.

As Table 1 indicates, at the end of the 1990s, the share of Italians who 185 considered themselves to be quite/very religious was significantly higher than the share of those who regarded themselves as being quite/very spiritual (78\% vs. 68\%). In 2006, the figures show a more equal ratio. The percentage of those who consider themselves to be quite or very religious (73\%) is roughly the same as the percentage of those who admit that their life is characterised by

190 medium or high spirituality (74\%).

Moreover, in comparison with RAMP 1998 (Garelli, Guizzardi and Pace), the percentage of respondents who identify themselves as medium to highly religious diminished by 5 percentage points, whereas the percentage of those who claim to lead a spiritual life has risen by 6 percentage points. At the same

195 time, the share of those who claim not to be religious or to be only a little religious increased (from $21 \%$ in 1998 to $25 \%$ in 2006); the share of those who do not lead a spiritual life decreased (from $28 \%$ in 1998 to $23 \%$ in 2006).

Although the majority of the sample (59\%) shows little or no interest in searching for the 'spiritual', 31\% of interviewees declare that they are 200 interested in spiritual matters and feel a greater need to cultivate a spiritual life now than they did in the past. Only $11 \%$ say they feel less of a need to do so.

In order to describe how Italians address spirituality, it is useful to focus on the relationship between religion, spirituality, and institutionalised organisations. Can a spiritual life be led independently from organised religion? More than $20580 \%$ of respondents believe that this is possible, whereas only $19 \%$ are not at all or only a little convinced of this. Although more than three quarters of respondents think that no anchorage with official institutions is necessary for leading a spiritual life, almost $66 \%$ believe that it is important to be part of a church or a religious community in order to grow spiritually; $36 \%$ do not agree or

210 do not think it is important. Remarkably, roughly half of Italians agree with the statement that one can lead a spiritual life without believing in the Christian God. Exploring this finding a little further, $27 \%$ of regular worshippers (that is, those who attend mass at least once a week) claim that the 'spiritual search' can be led 
independently of belief in God; if we consider those who attend mass at least one

215 a month, the share increases to $66 \%$.

A sceptical attitude towards traditional religious authorities is also clearly evident when one looks at the results of the questionnaire items on truth and salvation. Only 23\% express any agreement with the statement "only one religion is true". Despite statements from the Vatican affirming the absolute truth 220 of Catholicism, more than three quarters of respondents disagreed with this statement. Roughly two thirds affirm that "everybody can be saved independently from being religious and independently from the particular religion they belong to". Finally, more than half of respondents agree with the statement "it would be better if there were only one religion based on the main

225 beliefs of all religions, able to join together Christians, Muslims, Buddhists and other believers".

It is also important to note some statistics concerning involvement in 'holistic activities', seminars, courses, training, and reading about alternative spiritualities as well as interest in new religious movements. In answer to the question "Which

230 of these activities have you practised in the past years?", 9\% affirm they read texts or participated in meetings on "Eastern religions, philosophies and spiritualities"; $4 \%$ participated in seminars on "New Age and New Religious Movements" (at least occasionally); 6\% participated in 'holistic activities', such as yoga, Transcendental Meditation, Zen, etc. (at least occasionally).

235 In comparison with the figures shown by the project Religiosità in Italia of 1994, there is a slight increase of interest in these themes and in group participation. ${ }^{8}$

Although these data provide evidence that the 'holistic milieu' has grown, they do not necessarily mean a commensurate increase in the number of people who have been attracted to spirituality over the past years. Many of those attracted to

240 these activities could be looking for subjective well-being and thus be totally disinterested in the spirituality of the practices. In order to distinguish between practitioners who are spiritually engaged and those who are interested for other reasons, we must focus on the respondents' motivations for involvement in new spiritual activities. The majority (49\%) are prompted by an interest in cultural

245 enrichment-learning about other ways of life, perhaps because it's fashionable, perhaps to broaden the mind, perhaps in the spirit of tourism. Another $30 \%$ are looking for spiritual growth; $27 \%$ want to satisfy their curiosity; $12 \%$ hope to meet people who have the same interest; $10 \%$ aim to overcome stress and break their daily routine; $9 \%$ hope for help through difficult periods; $8 \%$ attend simply for

250 fun. The analysis of the questionnaire findings suggests that, for many, the desire for a spiritual quest is present, but it is accompanied by a strong cultural interest and by curiosity as to what these practices are all about.

Regarding the social milieu and the social-demographic groups which exhibit a higher affinity with such activities, the figures show that women are a little more

255 active than men. Secondly, cultural and spiritual interest as well as participation in the holistic milieu are more widespread in North Italy. Further, those involved are predominantly between 36 and 45 years old. As for educational background, returns from the questionnaire show that the majority has a university or secondary school degree.

260 Having presented survey data which demonstrate the increased of importance of spirituality, I now want to address the following question in more detail: what interpretation can be made based on this information? Even though it seems that 
Table 2. Cross Tabulation of Self-assessment of Religiosity and Spirituality (\%).

\begin{tabular}{llrrr}
\hline & & \multicolumn{3}{c}{ "Do you have a spiritual life?" } \\
\cline { 3 - 5 } & & NO & YES & Total \\
\hline “Do you consider yourself & Not religious & 23 & 8 & 31 \\
a religious person?" & I'am religious & 5 & 64 & 69 \\
& Total & 28 & 72 & 100 \\
$\mathrm{~N}=2171$ & & & \\
\hline
\end{tabular}

Source: The Italian Religion and Spirituality Project 2006.

Italians are now more interested in spirituality than they were in the past, the data do not lead to the conclusion that religion is giving way to spirituality, 265 nor that these categories are mutually exclusive. It is not necessarily the case that there is a sharp distinction between those who identify themselves as religious and those who claim to lead a spiritual life. The statistical analysis which shows the percentages of Italians who claim to be "religious" and/or "spiritual" (see Table 2), confirms that there is much overlap between the two

270 groups, proving that religion and spirituality need not be two different and incompatible worlds.

In response to the questions "Do you consider yourself a religious person?" and "Do you have a spiritual life?", those with a Likert ranking of 1-3 appear as 'not religious/spiritual' and those with a ranking of 5-7 appear as 'religious/

275 spiritual' (see Table 2). Where respondents entered the neutral value of 4 in one or both their answers, they were removed from the calculation. ${ }^{9}$ Over two thirds $(69 \%)$ of the remaining respondents consider themselves religious and roughly three quarters (72\%) think they have some kind of spiritual life. A quarter (26\%) of the non-religious and $93 \%$ of the religious consider themselves to be spiritual.

280 For the sake of brevity and clarity, most of the discussion will now focus on the four groups of respondents (presented in Table 2) who clearly fall into one of four categories: (1) neither religious, nor spiritual ('neither' $=23 \%$ ); (2) religious, but not spiritual ('only religious' $=5 \%$ ); (3) spiritual, but not religious ('only spiritual' $=8 \%$ ); and (4) both spiritual and religious ('both' $=64 \%$ ).

285 In two American studies (Zinnbauer et al.; Marler and Hadaway), the "both spiritual and religious" group was compared with the "spiritual, but not religious" group; the former was more likely to attend church and follow its teaching and doctrine, while the latter was more similar to the "highly active seekers" described by Roof. Such 'spiritual seekers' are reported to be exploring

290 the world's storehouse of faiths and spiritualities for a variety of meaning systems and practices with which to experiment, in order to find those that meet their needs. They may also be hostile to traditional or organised religion per se.

At the most general level, the questions I pursue now for the Italian sample 295 arise from these findings. Further details are provided about the composition of the four groups in order to point out some defining features of their religious and spiritual attitudes and practices. 
Table 3. Belief in God: "Which of these statements comes nearest to your own belief about the existence of God?" /one choice (\%).

\begin{tabular}{lcccc}
\hline & $\begin{array}{c}\text { neither religious } \\
\text { nor spiritual }\end{array}$ & $\begin{array}{c}\text { religious, } \\
\text { but not } \\
\text { spiritual }\end{array}$ & $\begin{array}{c}\text { spiritual } \\
\text { but not } \\
\text { religious }\end{array}$ & $\begin{array}{c}\text { both spiritual } \\
\text { and religious }\end{array}$ \\
\hline I believe that God does not exist & 21 & 3 & 16 & 2 \\
I have no interest in the existence of God & 22 & 4 & 15 & 1 \\
I believe in a higher power or life force & 11 & 3 & 19 & 1 \\
I believe in God from time to time & 18 & 15 & 16 & 4 \\
I believe in God with some doubt & 21 & 25 & 26 & 19 \\
I believe in God without any doubt & 7 & 50 & 8 & 73 \\
Total & 100 & 100 & 100 & 100 \\
$\mathrm{~N}=2171$ & & & & \\
\hline
\end{tabular}

Source: The Italian Religion and Spirituality Project 2006.

\section{Profiles}

Regarding gender and age, as one might expect, there is a clear gender difference when respondents were asked if they considered themselves religious or spiritual (76\% of women define themselves as "both spiritual and religious", compared to $56 \%$ of men, while $34 \%$ of men regard themselves as "neither religious nor spiritual", compared to $13 \%$ of women). However, there is almost no difference between males and females who consider themselves "only religious" or "only

305 spiritual". With regard to age, respondents under the age of 29 are most likely to call themselves "only spiritual". In fact, the share of the young (aged 18-29) who think they are "more spiritual than religious" (10\%) is more than double the share of the elderly (aged 66-74) who think so (4\%). While the option "only religious" increases with age, $83 \%$ of the elderly define themselves as "both spiritual and

310 religious". Similarly, the option "neither religious nor spiritual" unites $31 \%$ of the young (aged 18-29), but only 12\% of the elderly (66-74 aged).

Predictably, church attendance ${ }^{10}$ is higher for the "both spiritual and religious" group (68\% attend at least once a month) than for the "religious, but not spiritual" group (44\% attend at least once a month). On the other hand, $60 \%$ of

315 "only spiritual" group never go to church, nor do 57\% of those who regard themselves as "neither religious nor spiritual".

More interesting are the findings from the questions about religious beliefs. Concerning belief in God, $73 \%$ of those who reported to be "both spiritual and religious" believe in the Christian God without any doubt, while 23\% of them

320 believe in God with some doubt pertaining to God's existence. The share of those who believe in God without any doubt decreases to 50\% among the "religious, but not spiritual" group: $40 \%$ believe in God with some doubt. Among the "only spiritual" group, $42 \%$ believe in the Christian God, but with some doubt regarding God's existence, whereas $19 \%$ believe in a higher power or life force that does not correspond to the Christian God. As expected, $54 \%$ of those who are "neither religious nor spiritual" do not believe in God or have no interest in this matter. 
Table 4. Life after death: "What happens to us after death?" /one choice (\%).

\begin{tabular}{|c|c|c|c|c|}
\hline & $\begin{array}{c}\text { neither } \\
\text { religious } \\
\text { nor spiritual }\end{array}$ & $\begin{array}{l}\text { religious, } \\
\text { but not } \\
\text { spiritual }\end{array}$ & $\begin{array}{l}\text { spiritual, } \\
\text { but not } \\
\text { religious }\end{array}$ & $\begin{array}{l}\text { both spiritual } \\
\text { and } \\
\text { religious }\end{array}$ \\
\hline Nothing-death is the end. & 38 & 9 & 30 & 5 \\
\hline There is something, but I don't know what. & 25 & 25 & 20 & 15 \\
\hline $\begin{array}{l}\text { It is not possible to know what happens to } \\
\text { us after death. }\end{array}$ & 26 & 35 & 28 & 17 \\
\hline After death there is a new life. & 9 & 28 & 15 & 57 \\
\hline $\begin{array}{l}\text { We are reincarnated-that is, after our } \\
\text { physical death, we are born in this world } \\
\text { over and over again. }\end{array}$ & 1 & 3 & 6 & 4 \\
\hline Other & 1 & - & 1 & 2 \\
\hline Total & 100 & 100 & 100 & 100 \\
\hline $\mathrm{N}=2171$ & & & & \\
\hline
\end{tabular}

Source: The Italian Religion and Spirituality Project 2006.

Equally important is belief in Jesus Christ. It is remarkable that $40 \%$ of the "spiritual, but not religious" respondents do not believe at all in the statement

330 that "Jesus Christ is God's son" and that $44 \%$ of them do not believe at all in his resurrection. These figures are higher than those relating to the "neither religious nor spiritual" group: $32 \%$ do not believe in the statement that "Jesus Christ is God's son" and 37\% do not believe in his resurrection.

Regarding the conception of death, the "spiritual, but not religious" group

335 is most likely to opt for reincarnation (6\%). Many more (30\%) choose the option "Nothing. Death is the end"; $28 \%$ opt for "It is not possible to know what happens to us after death". Table 4 shows respondents' answers to the question of what they think is likely to happen to them after they die.

\section{Opinions about Religious Pluralism}

340 Italians who reported that they are "only spiritual" are most likely to opt for the idea that "people should be free to mix and match different religious traditions and practices" (31\%, compared to $13 \%$ of those who consider themselves as "both spiritual and religious"). They also disagree more frequently with the question: "Do you think that it is good that missionaries spread the message of

345 their religion to other cultures?" (74\%, compared to 35\% of those who regard themselves as "both spiritual and religious"). Further, the majority in this group think that "anybody can be saved because salvation doesn't exist" (48\%). By contrast, those who regard themselves as "only religious" are most likely to opt for the idea that "it would be better to take root in their own faith and religion

350 rather then searching for other ones" (80\%). Similarly, 78\% of those who say they are "both spiritual and religious" think so.

\section{Opinions about Spirituality}

Among those who agree with the item "Could a spiritual life be led independently from organised religion?", the proportion who report that they 


\section{S. Palmisano}

355 are "neither religious nor spiritual" is the same as for those who regard themselves as "both spiritual and religious" (78\%). This figure is lower for the "religious, but not spiritual" group (65\%), but rises to $97 \%$ among the "spiritual, but not religious" group. The latter is also most likely to opt for the statement that "it's possible to lead a spiritual life independently from God". Only 35\% of the

360 "religious, but not spiritual" respondents agree, a little more than those who are "both religious and spiritual" (31\%). Not unexpectedly, but still significantly, the "spiritual, but not religious" group is the most engaged in "holistic activities" and "meetings on alternative spiritualities". It should be noted that, although it seems that those who are "only spiritual" are more likely

365 to collect ideas, styles, and practices from multiple traditions, they do not usually import practices, images or symbols belonging to different religions into everyday life. It thus seems that the openness to learn about different religions or spiritualities-to be a spiritual tourist-is more connected to spheres of knowledge than to spheres of experience. This inclination could also be

370 supported by the fact that, as shown above, roughly half of those who are attracted by "holistic proposals" are motivated by an interest in cultural enrichment.

The data described above suggest further thoughts. As seen in this section, some of the $8 \%$ of Italians who reported that they were "a spiritual person", 375 but not a "religious person", almost certainly had in mind an idea of spirituality which is far from religion: the great majority of this group never attend church. However, a small group who are "only spiritual" attend church at least once a month. For them, "spiritual, but not religious" could be not an actual rejection of religion, but a reminder to sustain spiritual vitality within 380 traditional religion. Besides, many people might prefer to define themselves as 'spiritual' rather than 'religious', because 'religion' is felt to be too dogmatic, intolerant, associated with hierarchy, and perhaps dangerous. Finally, it should be borne in mind that many respondents (10\%) who regard themselves to be "only spiritual" are under 29 years old. According to Smith and Denton, they 385 might use this category not to distance themselves from organised religion per se, but to emphasise the importance of a personally meaningful faith that can also be practised in the context of organised religion.

Although the percentage of those who identify themselves as "a religious person", but not "a spiritual person" (5\%) is not all that helpful in ascertaining

390 what spirituality means, it helps us to discern something about the characteristics of what is being rejected. The group who is "only religious" may well include conservative Catholics who are highly suspicious of 'spirituality', because they associate it with the idea of the 'New Age'. Thus, even considering the experiential dimension of their faith, they regard themselves as "only

395 religious" because of fearing to be confused with the "spiritual seekers" - the easy prey of spiritual relativism which Pope Benedict XVI has repeatedly condemned. Moreover, many Italians might define themselves as "only religious", because, although now totally or partially disengaged from religion, they were born in a Catholic country, attended Catholic schools, youth groups,

400 and oratories, went to mass, had Communion and Confirmation, and married in a Catholic church. They feel that they belong to Catholicism-as an important aspect of the Italian way of life-but they are not officially or formally members. For them, belonging to Catholicism is an ethnic and 
cultural rather than a religious membership (Garelli, Forza). This suggestion is supported by the figure for church attendance: among the "only religious", the majority attends mass at most once a year, while only a small group attends at least once a week.

To conclude this section, a brief summary of the key findings so far: (1) the language of spirituality has entered Italian popular consciousness and there is

410 much evidence to lead to the conclusion that Italians are now much more interested in what spirituality is about than they were in the past. Firstly, the percentage of those who admit that their lives are characterised by medium to high spirituality (74\%) is now roughly the same as that of those who consider themselves to be quite or very religious (73\%). Secondly, 31\% of Italians declare

415 that they now have a greater need to cultivate a spiritual life than they had in the past. Thirdly, compared to 1994, there is a slight increase in interest in meetings, reading, etc., which involves alternative spiritualities, and in participation in the holistic milieu. Finally, the range of the well-being culture and references to holistic practices, way of life, and thinking has increased in many areas,

420 whether health or work, consumption or school; this may not be reliable evidence of 'belief' in spirituality, but is indicative of such interest among teachers, holistic spa owners, etc. ${ }^{11}$ This raises the question whether spirituality will become culturally more influential in the coming years. (2) At least two types of spirituality emerge from the questionnaire responses: one associated with 425 religion, the other not associated with religion.

\section{Distinguishing Spiritualities}

As discussed, Italians have shown an increases interest in the quest for 'spirituality'. This evidence directs us to the major questions of this article. In a nation where Catholicism is the prevailing religion and where there are

430 few atheists, why do so many use the language of spirituality? Further, why do $8 \%$ of Italians consider themselves as "only spiritual"? More generally speaking, what is meant by 'spirituality' in the different contexts in which it is used?

As indicated, the concept gives rise to problems of interpretation. It certainly

435 seems to be associated with a plethora of meanings: it means different things to different people. In line with Zinnbauer et al.'s findings for the US, some see it as complementary to religion, others in opposition to religion, and yet others understand the two concepts as having a more complicated relationship, with one encompassing or overlapping with the other. With respect to the findings

440 for Italy, it is important to distinguish between two fundamentally different kinds of spirituality, as shown in this study: (a) we might call the former 'intra-religious spirituality' - in Italy's case, 'Catholic spirituality'. This presumes that the religious experience is linked with the sacred which is and remains 'external to' and 'higher' or 'out there' (typically the Christian God). Three logical possibilities can be derived from

445 this (see Table 5): spiritual life reliant on God, spiritual life reliant on the Church, spiritual life reliant on both. It could be suggested that people who define themselves as "both spiritual and religious" predominantly lead a spiritual life linked to God and the Church. 
Table 5. Spirituality: Logical possibilities.

\begin{tabular}{ll}
\hline degree of spirituality & \multicolumn{1}{c}{ logical possibilities } \\
\hline intra-religious spirituality & $\begin{array}{l}\text { reliant on God } \\
\text { reliant on Church } \\
\text { reliant on God and Church } \\
\text { independent of both }\end{array}$ \\
\hline
\end{tabular}

Table 6. Selected responses, ranked in order of frequency, to the question "What does the word 'spirituality' mean to you?".

"What does the word 'spirituality' mean to you?"

1. To strive for a state of harmony and inner peace in yourself and in the others

2. Seeking the meaning of life

3. Seeking the inner self, developing your spiritual qualities

4. Seeking to be a good person, lead a good life

5. Belief in God, following his teachings

6. To help others and give your time to others

7. To be able to distinguish between right and wrong

8. Belief in higher, transcendent power, something beyond oneself

9. To affirm sense of personal worth, to affirm one's capabilities in everyday life

10. Going to church and following its expectations

Source: The Italian Religion and Spirituality Project 2006.

(b) By contrast, the latter might be called 'extra-religious spirituality' and referred 450 to as a form of spirituality that is associated neither with the Church nor with God, as represented by theistic Christianity (see Table 5).

In order to analyse which concept of spirituality Italians have in mind and to suggest what a more detailed interpretation could explore, I focus on the responses to the question "What does the word 'spirituality' mean to you?".

455 Provided with a list of characterisations based on Gallup and Jones (49), respondents were asked to say if these were related to the meaning of spirituality. ${ }^{12}$ Italians' responses are summarised in Table 6, ranked in order of frequency.

About $88 \%$ attach the following meaning to 'spirituality': "To strive for a state 460 of harmony and inner peace in yourself and in others"; only 51\% select "Going to church and following its expectations".

The findings from the statistical analysis, which we carried out in the search of possible meanings of the term 'spirituality', are arresting. Principal Components Analysis reveals three dimensions. ${ }^{13}$ I call the first factor ethic spirituality, because 465 it is predominantly associated with the following items: "To try to be a good person and to lead a good life", "To demonstrate one's value and one's capabilities in everyday life", "To help others and give your time to others", "To be able to distinguish between right and wrong". I define the second factor religious spirituality, because it is related to the items: "To believe in

470 God and follow his teachings", "To believe in a higher, transcendent power", "To go to Church and to follow its expectations". The third factor is inner-self 
(or inner-life) spirituality. It is linked with the items: "To strive for a state of harmony and internal peace in yourself and in others", "To look for your inner self, to develop your spiritual qualities", "To look for the meaning of life".

The main ideas that Italians associate with the meaning of 'spirituality' thus relate to three profiles: ethic spiritualities, religious spiritualities, and inner-self or inner-life spiritualities. These profiles do not necessarily describe what goes on 'out there'. They are analytic tools intended to facilitate the comparison of ways of thinking about-and perhaps ways of living — spirituality. They appear

480 as clusters where individuals and groups may belong in one category in many respects, but neither individuals nor groups always neatly fit any one type. Further, each cluster could be combined with other clusters.

The three profiles can be described in further details as follows. Firstly, by definition, religious spiritualities are spiritual forms of an intra-religious kind.

485 It is evident from the analysis of the profile that this kind of spirituality is the closest to 'traditional religion'. This conception of the divine involves a God who is essentially located beyond this world, acting upon this world and life within it. The root experiences of religious spiritualities could be, for instance, temporary retreats for religious exercises in monasteries, churches, and abbeys or trips

490 in the natural environment to admire God's creation (see Flanagan's notion of 'Visual Spirituality', 219). All these experiences enable believers to enter into an intense relationship with the divine-who is and remains transcendent, separate from the believer, over and above the self. According to Heelas's distinction ("Spiritual Revolution" 3), three forms of religious spirituality can be pointed

495 out, which might help explain the varieties of religious spirituality, in which Italians are involved:

- transcendent spirituality or mystical experiences as ineffable events which confirm the truth of religious orthodoxy

- holy spirituality, which is the experience of the indwelling Holy Spirit; it

500 is very common among Italians influenced by Charismatic or Pentecostal movements

- theistic humanism, a form of experiencing relationships with God's creations, which is very common in believers who emphasise the human values and sentiments of their faith rather than abstract doctrines and dogmas

Secondly, ethic spiritualities are connected to the ethical dimensions or meanings of life; they concern the basic attributes, capacities, capabilities, potential of individuals, and communal life. The analysis of this profile shows that the nature of the spiritual life of those who define spirituality mainly in this way

510 is linked to their own qualities, such as goodness, creativity, sense of right and wrong, authenticity, wisdom, and sensitivity. The data from the Italian study do not point to a clear difference between the genders; nevertheless, it can be said that ethic spiritualities increase with age. Concerning the relationship with religion, many individuals who adhere to ethic spirituality seem to refer

515 to religion in an ethnic, cultural or national way. For them, in addition to representing 'true' membership, anchorage in the Catholic Church predominantly serves to provide something akin to 'a sacred canopy', to which they refer in ordinary life or on special occasions. It could be suggested that, for some, ethic spirituality is basically intra-religious in nature, albeit with less 


\section{S. Palmisano}

520 emphasis on obedience to the theistic Godhead than is typical of theistic humanism. For others, the emphasis lies with the extra-religious-the cultural, for example. For yet others, a mixture is clearly in evidence. At least this is the working hypothesis.

Thirdly, inner-self or inner-life spiritualities do not just simply involve

525 'unchurched spirituality', but also 'non-Christian/theistic spirituality'. These terms refer more closely to the concept described in the social-scientific literature as 'New Age spiritualities' or 'Alternative Spiritualities' (see Partridge). Most participants in the New Age milieu, it is argued, collect an apparently incoherent set of spiritual ideas and practices, which draw upon

530 multiple traditions. New Age is thus described as a 'do-it-yourself religion', 'pick-and-mix religion' or a 'spiritual supermarket' (see Houtman and Aupers, "Spiritual Supermarket"). Yet beneath much of that heterogeneity is a remarkable constancy: the same lingua franca (to use Heelas's useful expression), the language of Self-spirituality. The great refrain of the language of the self is that it is

535 fundamental to break away from mainstream society and culture to experience owning one's 'authentic', 'natural' or 'real' self. Regarding the Italian situation, these kinds of attitudes and sensitivities are better described as 'inner-self or inner-life spiritualities' instead of 'New Age spiritualities'. Inner-self or inner-life spiritualities comprise a variety of spirituality that concerns the force,

540 energy or vitality that sustains life itself; they are bound up with the subjective life of each individual and his/her own self. In this sense, 'inner-self or inner-life spiritualities' can be distinguished from 'religious spiritualities': the latter are associated with life lived according to the will of God, as a member of a community or a religious tradition, where what matters is obeying, heeding

545 and pursuing ways of life in conformity to external expectations; the former are associated with life lived in close connection with the own unique self that thus became the main source of authority and significance (Heelas, "Spiritual Revolution" 3-4).

Analysis of inner-self or inner-life spirituality profiles allows for a deeper understanding of the nature of these varieties of spirituality. First of all, two thirds of Italians who associate spirituality with 'inner-self or inner-life spiritualities' think that one can lead a spiritual life without believing in the Christian God. Predictably, the unchurched (Hunt 159) show a very low level of religious spirituality, but show instead a high level of inner-self or inner-life

555 spiritualities. In addition, according to the gender puzzle, which Woodhead summarises in the question "Why so many women in holistic spirituality?" (120), the data reveal that inner-life spiritualities are much more in evidence in women than in men. Regarding age and education, younger people and those with higher levels of education show a higher level of affinity with this

560 kind of spirituality than the older generations and those with lower levels of education.

\section{The 'God within' ...}

Three different profiles of spirituality have been described above. One further issue needs to be raised. If religious spiritualities are related to the Christian God, which image of the divine (if there is one) can be supposed to be associated with 
inner-self or inner-life spiritualities and also with ethic spiritualities? To answer this question, it seems useful to start with the answers to the question about the images of God, to which Italians responded in RAMP 1998. Although it is ten years old, this is the only existing set of data which specifically concerns Italians' opinions about the nature of God. It addresses them in three different ways: (1) It shows the most widespread images of God in Italy; (2) it enables us to point out which image of the divine is preferred by people who regard themselves as "both spiritual and religious", "spiritual, but not religious", "religious, but not spiritual" or "neither religious nor spiritual"; and (3), it

575 suggests which image of God could be predominantly associated with inner-self or inner-life spiritualities and ethic spiritualities.

The RAMP 1998 data reveal that the largest group of Italians (50\%) believes "in a God with whom I can have a personal relationship", followedunexpectedly-by 36\% who believe "that God is something within each person 580 and in nature". Only 5\% do not believe in any kind of God or life force and 7\% believe in a higher power or spirit that does not correspond to the Christian God. It is absolutely extraordinary that more than a third of Italians associate the divine with an entity that does not correspond to the Christian God, but is, by contrast, immanent and cosmic: 'the god within' is thought to be an integral

585 part of the human being, who may, in turn, be conceptualised as an integral part of nature and/or of the cosmos ('in nature').

The answers of the four groups ("both spiritual and religious", "spiritual, but not religious", "religious, but not spiritual", "neither religious nor spiritual") to the same question (Table 7) point to a pattern which clearly supports the supposition that God means something different to them.

Table 7. Concept of God: "Which of these statements comes nearest to your own belief?", one choice (\%).

\begin{tabular}{lcccc}
\hline & $\begin{array}{c}\text { neither religious } \\
\text { nor spiritual }\end{array}$ & $\begin{array}{c}\text { religious but } \\
\text { not spiritual }\end{array}$ & $\begin{array}{c}\text { spiritual but } \\
\text { not religious }\end{array}$ & $\begin{array}{c}\text { both spiritual } \\
\text { and religious }\end{array}$ \\
\hline $\begin{array}{l}\text { I believe in a God with whom } \\
\text { I can have a personal } \\
\text { relationship. }\end{array}$ & 21 & 50 & 20 & 67 \\
$\begin{array}{l}\text { I believe in a higher power or } \\
\text { life force that does not } \\
\text { correspond to the }\end{array}$ & 16 & 5 & 18 & 2 \\
$\begin{array}{l}\text { Christian God. } \\
\begin{array}{l}\text { I believe that God is } \\
\text { something within each } \\
\text { person and in nature. }\end{array}\end{array}$ & 37 & 43 & 46 & 30 \\
$\begin{array}{l}\text { I don't believe in any kind } \\
\text { of God, spirit or life force. }\end{array}$ & 20 & 1 & 14 & 0 \\
$\begin{array}{l}\text { I really don't know what } \\
\text { to believe. }\end{array}$ & 6 & 1 & 2 & 1 \\
$\begin{array}{l}\text { Total } \\
\mathrm{N}=1390\end{array}$ & 100 & 100 & 100 & 100 \\
\hline
\end{tabular}

Source: RAMP 1998. 
Of those who say they are "both religious and spiritual", over two thirds believe in the Christian God. They appear to be religious in the more traditional sense than the respondents who are "religious, but not spiritual"; they think of the divine as both the theistic God (50\%) and the immanent $(43 \%)$. By contrast, the relative majority of those who think of themselves as "only spiritual" believe in the "god within and in nature" (46\%). The conceptualisations of God of those who regard themselves as "neither religious nor spiritual" (those who have an image of the divine) are very different: they vary from the theistic God, the 'god within' to a "higher power that does not correspond to the Christian God".

These data lead to the following hypothesis: the image of the divine is connected to 1. "religious spiritualities", 2. "inner-self or inner life-spiritualities", and 3. "ethic spiritualities". This would allow us to draw a map of spirituality within the sacred sphere of Italy.

605 It is clear that the first group ("both religious and spiritual"), who mainly believe in a transcendent God, is the home of "religious spiritualities". If situated on a spectrum that maps the degree of movement from traditional mainstream, this is probably the most orthodox position. Every variety of these spiritualities (transcendent spirituality, holy spirituality, theistic humanism) is 610 understood to emanate from the transcendent realm to serve life in this world.

The opposite position-the "only spiritual" group—is the most heterodox in terms of belief in God. It could be supposed that those who predominantly believe in the "god within and in nature" attach the meaning of spirituality mostly to what I call 'inner-self or inner-life spiritualities'. For them, the

615 meaningful nature of spiritual life is about living life in authentic connection with the inner depth of their unique self. Their goal is not to defer to higher authority, but to become their own authority. Thus inner-self or inner-life spiritualities might be related with a divine that is "within and in nature", immanent and cosmic. According to Lynch, who states that this notion of the

620 divine can take either pantheist or panentheist forms, inner-self or inner-life spiritualities promote the sacralisation of nature as the site of divine presence and activity in the cosmos as well as the sacralisation of the self. The Italian Religion and Spirituality Project 2006 reveals a pattern which clearly supports the supposition that among those who understand spirituality as "inner self or inner

625 life spiritualities", 10\% associate the divine with something that does not correspond to Christian God-a figure which much higher than the figures of the other profiles of spirituality.

The question where the "only religious" group could be placed on the hypothetical map is more complex, as this group divides into two sub-groups:

630 those who associate the divine with the theistic God (50\%) and those who associate it with the immanent "god within and in nature" (43\%). It seems that two different issues are present in this group: the first is very much bound up with religious tradition, while the second is totally or partially disengaged from religion. The first sub-group is probably the most religiously conservative

635 (even more conservative than the group who are "both religious and spiritual"); it is different from religious spiritualities in that the language of spirituality is rejected as being too deviant. The second sub-group is most likely to embrace ethic spiritualities. One would expect to find people here for whom belonging to Catholicism is more an ethnic and cultural rather than a religious membership. 
Table 8. An hypothetical map of spirituality within the sacred in Italy.

\begin{tabular}{|c|c|c|c|c|}
\hline & $\begin{array}{l}1 \text { "only religious" } \\
\text { (not spiritual) }\end{array}$ & 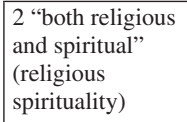 & \begin{tabular}{|l}
3 "only \\
religious" (ethic \\
spirituality)
\end{tabular} & $\begin{array}{l}4 \text { "only spiritual" (inner } \\
\text { self or inner life } \\
\text { spirituality) }\end{array}$ \\
\hline & God transcendent & God transcendent & god within & god within \\
\hline $\begin{array}{l}\text { orthodox } \\
\text { position }\end{array}$ & & & & $\begin{array}{l}\text { heterodox } \\
\text { position }\end{array}$ \\
\hline
\end{tabular}

640 Catholicism is relatively detraditionalised for them, but they nevertheless adhere to key 'Catholic' values which are underpinned by the Catholic belief that all human life is sacred-the God of human life-cum-Catholic values. Accordingly, in Table 8 the group is sub-divided into two, with each sub-group occupying a different position: the most conservative (those who associate the

645 divine with the theistic God) are at one end of the spectrum and the second sub-group, who are most likely to embrace ethic spirituality, are between religious spirituality and inner-self or inner-life spirituality. Therefore, in Table 8, group 1 represents those who are "only religious" (not spiritual)—they believe in a transcendent God; group 2 are "both religious and spiritual" - they

650 believe in a transcendent God; group 3 are "only religious", ethically spiritualthey believe in the "god within"; group 4 are "only spiritual" — they relate to inner-life spirituality and believe in the "god within".

This analysis raises further questions. We still have to understand the meaningful nature of the spiritual life of people who show forms of belief 655 in God, which differ from the main choice of the group to which they belong. For instance, there are those who define themselves as "both religious and spiritual", but state belief in the "god within and in nature". Then there are those who are "neither religious nor spiritual" and believe in the theistic God as well and those who believe in the "god within and in nature". It is

660 possible that people who are "neither religious nor spiritual", but believe in the "god within and in nature", might be thinking more in terms of 'ethic spirituality". Yet they do not know the language of spirituality and thus do not refer to it.

Future research will need to make sure that questionnaires include multiple 665 choice answers, both ranked and not ranked. Individuals might then state that they believe in different conceptions of God at one and the same time (for example, belief in the god within and the God without). This would allow for a much richer picture to emerge.

\section{Conclusion}

670 The present research is a first attempt to explore-at both theoretical and empirical level-the distinction between religion and spirituality in Italy. Although alternative spiritualities might be regarded as a largely Protestant phenomenon, it has been shown that such spiritualities are also significant 
within Italian Catholicism. However, even though it seems that Italians are now more interested in spirituality than they were in the past, the data do not lead to the conclusion that Italian Catholicism is giving way to unconventional spirituality. The statistical analysis which shows the percentages of Italians who claim to be "religious" and/or "spiritual" confirmed that there is much overlap between these two groups; this proves that in the Italian popular consciousness, religion and spirituality are not two different and incompatible worlds.

Regarding these findings, it is important to observe that, for the majority of Italians, the concept of 'spirituality' indicates an individual's relationship with God and is focused on the personal, intimate, and subjective aspects of

685 this relationship. The dimension of affectivity and emotion is where one can experience a profound and immediate unity with all that is absolute. This kind of spirituality is referred to as intra-religious spirituality (or 'Catholic spirituality'), because it presumes that the religious experience is linked with the sacred which is and remains 'external to' and 'higher' than the individual (typically the

690 Christian God).

At the same time, this study reveals that, undoubtedly, a form of unconventional spirituality (what might be called extra-religious spirituality), based on personal experience and associated with neither the church nor God as represented by theistic Christianity, is growing. The percentage of Italians who

695 describe themselves as spiritual, but not religious - privileging the 'God within' rather than the transcendent God of traditional Catholic belief-has been rising during the last decade.

Therefore, the data presented here strongly suggest that it is high time for Italian sociologists of religion to take on board the study of spirituality,

700 in order to understand more clearly Italy's religious and spiritual landscape, as it is presently in the process of reconstituting itself.

The present quantitative data will need to be supplemented with qualitative work, in order to specifically examine further what assortment of beliefs, practices, and activities falls into the category of 'alternative spirituality' and

705 analyse whether people find a spiritual dimension in those activities (whether they are part and parcel of the secularisation process or able to sacralise social and even personal life). An underlying issue is whether unconventional spirituality in contemporary Catholicism is a symptom of secularisation, as Voas and Bruce (53) maintain; they argue that many participants of the holistic

710 milieu do not consider their activities to be of spiritual significance. Or might spirituality be a durable counterforce to secularisation, as Heelas notes in "The Infirmity Debate" (232). He claims that the vast majority of those in the holistic milieu who consider themselves as 'spiritual' show an extraordinarily high interest in unconventional beliefs. This gives rise to a number of pressing

715 questions which need to be addressed: does the phenomenon of spirituality draw attention to defects within Catholicism? Is its emergence affected by secularisation or by the rise of superstition? What can be said about the state of popular religion in Italy today?

There is thus much further work to be done, but this study furnishes valuable 720 pointers to considerable religious change in Italy, of which very little has appeared in the Italian sociology of religion literature so far. 


\section{Acknowledgements}

I would like to thank the two anonymous reviewers of the Journal of Contemporary Religion for their helpful comments and advice. Thanks are also due to Janet Eccles, Franco Garelli, Paul Heelas, and Linda Woodhead for their most helpful suggestions and material.

Stefania Palmisano is a Lecturer in Organization Studies, attached to the Department of Social Sciences at the University of Turin, Italy. She is currently a Visiting Research

730 Fellow in the department of IAS and Religious Studies at Lancaster University, UK. CORRESPONDENCE: stefania.palmisano@unito.it

\section{NOTES}

1. The Italian Religion and Spirituality Project was funded by CRT, the Italian Unicredit Bank's Private Foundation.

2. Profile of the sample (representative of the population as a whole in all the areas mentioned), regarding gender. Almost equal numbers of men and women represented, with just a slight bias in favour of women, corresponding to the Istat (National Statistical Institute) data updated on 1 January 2006. Regarding age, teenagers and young adults (aged 16-35) make up a little more than a third (34\%) of the sample, while the largest group (39\%) consists of adults (aged 36-55). Mature and elderly people (aged 56-74) represent under a third (27\%) of the sample. Regarding education, half the interviewees (51\%) completed only compulsory education (until age 14 in Italy). The remainder is composed of high-school leavers (36\%) and university graduates (12\%). Regarding marital status, two thirds of the sample are or were married (including those widowed/separated/divorced/re-married), while $30 \%$ are single and $4 \%$ are cohabiting. The majority of the sample have at least one child $(61 \%)$. Around half $(49 \%)$ have two children. Regarding religion, $86 \%$ of the interviewees identified themselves, at least nominally, as Catholic. The second largest group (9\%) consists of respondents who identified themselves as having 'no religion'. The presence of 'other religions' amount to about 5\%. 26\% of Catholic respondents attend Mass at least once a week; $14 \%$ of them never.

3. A version of the present work, together with an analysis of contemporary Italian Catholicism, will be published in book form, in both Italian and English. Tables are taken from the report which I compiled for the Religion and Spirituality Project 2006.

4. Comparison will be made with two recent studies in particular: the project Religiosity in Italy of 1994, whose chief findings are published in Cesareo et al. and the Italian section of the RAMP (Religious and Moral Pluralism) survey of 1998, whose chief findings are published in Garelli, Guizzardi and Pace.

5. Indagine Multiscopo 1999/2000. The data in this study were collected by Istat (Italian National Statistical Institute) in 1999; the sample included about 30,000 families, representing 70,000 individuals.

6. See the web site of Associazione Italiana Operatori del Benessere (Italian Association of Wellness) at www.aiob.it.

7. See my interviews with the Intesa-Sanpaolo top management during Summer 2007 (Palmisano).

8. See the project Religiosity in Italy of 1994, whose chief findings are presented in Cesareo et al. The data were collected in 1994, in a survey which covered all of Italy. The sample included 4,192 individuals and was representative of the Italian population of men and women whose ages ranged between the 16 and 74 .

9. In removing the neutral value of 4 in one or both answers, we have chosen, for the purpose of convenience, to follow the method used by Barker in her analysis of RAMP data.

10. I refer mainly to attendance of mass, because $86 \%$ of Italians identify themselves, at least nominally, as Catholic. 
11. The evidence I have provided cast doubt on the figures described in the World Values Survey of 1990 and 2000, which states that Italy is the only country where spirituality has been in decline since 1981.

12. The list of definitions was inspired by the list in Gallup and Jones (49). The original was modified to the Italian situation.

13. Principal Components Analysis of the questionnaire data demonstrates that three dimensions can explain $62 \%$ of the variance of responses. The first influences the variance for $26 \%$ of the respondents' selections, the second does so for $18 \%$, and the third for $17 \%$.

\section{REFERENCES}

Abbruzzese, Salvatore. "Il posto del sacro." Ed. Renzo Gubert. La via italiana alla postmodernità: Verso una nuova architettura dei valori. Milano: Franco Angeli, 2000. 397-455.

Barker, Eileen. "The Church Without and the God Within: Religiosity and/or Spirituality?" Eds. Irena Borowik, Dinka Marinović Jerolimov, and Siniša Zrinščak. Religion and Patterns of Social Transformation. Zagreb: Institute for Social Research, 2004. 23-48.

Borowik, Irena, Dinka Marinović Jerolimov, and Siniša Zrinščak, eds. Religion and Patterns of Social Transformation. Zagreb: Institute for Social Research, 2004.

Cesareo Vincenzo, Roberto Cipriani, Franco Garelli, Clemente Lanzetti, and Giancarlo Rovati, eds. La religiosità in Italia. Milano: Mondadori, 1995.

790 Diotallevi, Luca. Il rompicapo della secolarizzazione italiana: Caso italiano, teorie americane e revisione del paradigma della secolarizzazione. Soveria Mannelli: Rubbettino, 2001.

Flanagan, Kieran. "Introduction." Eds. Kieran Flanagan, and Peter C. Jupp. A Sociology of Spirituality. Aldershot: Ashgate, 2007. 1-21.

Flanagan, Kieran, and Peter C. Jupp, eds. A Sociology of Spirituality. Aldershot: Ashgate, 2007.

795 Gallup, George Jr., and Timothy Jones. The Next American Spirituality: Finding God in the Twenty-First. Colorado Springs: Chariot Victor, 2000.

Garelli, Franco. La religione dello scenario: La persistenza della religione tra i lavoratori. Bologna: Il Mulino, 1986.

-- -. Forza della religione e debolezza della fede. Bologna: Il Mulino, 1996.

800 ---. L'Italia cattolica nell'epoca del pluralismo. Bologna: Il Mulino, 2006.

Garelli, Franco, Gustavo Guizzardi, and Enzo Pace, eds. Un singolare pluralismo: Indagine sul pluralismo morale e religioso degli italiani. Bologna: Il Mulino, 2003.

Giarelli, Guido, Paolo Roberti di Sarsina, and Bruno Silvestrini, eds. Le medicine non convenzionali in Italia. Milano: Franco Angeli, 2007.

805 Giordan, Giuseppe. "Dalla religione alla spiritualità: una nuova legittimazione del sacro?." Quaderni di Sociologia 35 (2004): 105-17.

---, ed. Tra religione e spiritualitá: Il rapporto con il sacro nell'epoca del pluralismo. Milano: Franco Angeli, 2006.

Goleman, Daniel. Emotional Intelligence. New York: Bantam Books, 1995.

810 Heelas, Paul. "The Infirmity Debate: On the Viability of New Age Spiritualities of Life." Journal of Contemporary Religion 21 (2006): 223-40.

---. "Challenging Secularization Theory: The Growth of 'New Age' Spiritualities of Life." The Hedgehog Review: Critical Reflections on Contemporary Culture. After Secularization Spring/ Summer 8.1/2 (2006): 46-58.

815 --.. "The Spiritual Revolution of Northern Europe: Personal Beliefs." Nordic Journal of Religion and Society 20 (2007): 1-28.

Heelas, Paul, and Linda Woodhead. The Spiritual Revolution: Why Religion is Giving Way to Spirituality. Oxford: Blackwell, 2005.

Houtman, Dick, and Stef Aupers. “Oriental Religion in the Secular West: Globalization, New Age, and

820 the Re-enchantment of the World." Journal of National Development 16.1/2 (2003): 67-86. Journal of Contemporary Religion 21 (2006): 201-22.

Hunt, Kate. "Understanding the Spirituality of People Who Do Not Go to Church." Eds. Grace Davie, Paul Heelas, and Linda Woodhead. Predicting Religion: Christian, Secular and Alternative Features. Ashgate: Aldershot, 2003. 159-69.

Istat. Indagine Multiscopo "Condizione di salute e ricorso ai servizi sanitari". Rome: Istat, 1999/2000. 
Ketola, Kimmo. "Spiritual Revolution in Finland? Evidence from Surveys and the Rates of Emergence of New Religious and Spiritual Organizations." Nordic Journal of Religion and Society 20 (2007): 29-39.

830 Lynch, Gordon. The New Spirituality: An Introduction to Progressive Belief in the Twenty-first Century. London: I.B.Tauris, 2007.

Marler, Penny Long, and Kirk C. Hadaway. "Being Religious or Being Spiritual in America: A Zero-Sum Proposition?" Journal for the Scientific Study of Religion 41 (2002): 289-300.

Palmisano, Stefania. Uguali e diverse: Due banche a confronto. Roma: Carocci, 2006.

835 Partridge, Christopher. The Re-Enchantment of the West. Vol. 1. London: T \& T Clark, 2004.

Roof, Wade Clark. A Generation of Seekers: The Spiritual Journeys of the Baby Boom Generation. Princeton, NJ: Harper Collins, 1993.

Smith, Christian, and Melinda Lundquist Denton. Soul Searching: The Religious and Spiritual Lives of American Teenagers. New York: Oxford UP, 2005.

840 Taylor, Charles. Sources of the Self: The Making of the Modern Identity. Cambridge: Cambridge UP, 1989. Voas, David, and Steve Bruce. The Spiritual Revolution: Another False Down for the Sacred. Eds. Kieran Flanagan, and Peter C. Jupp. A Sociology of Spirituality. Aldershot: Ashgate, 2007.

Woodhead, Linda. "Why So Many Woman in Holistic Spirituality? A Puzzle Revisited." Eds. Kieran Flanagan, and Peter Jupp. The Sociology of Spirituality. Aldershot: Ashgate, 2007. - -

845 Zinnbauer, Brian J., Kenneth I. Pargament et al. "Religiousness and Spirituality: Unfuzzying the Fuzzy." Journal for the Scientific Study of Religion 36 (1997): 549-64. 